Persp. Teol. 36 (2004) 75-97

\title{
RAHNER NA BERLINDA PÓS-CONCILIAR
}

\author{
Luciano Campos Lavall
}

RESUMO:

O artigo analisa algumas críticas negativas feitas ao pensamento teológico de Karl Rahner, após sua morte, que tentam desqualificar a sua importância para a ortodoxia católica e o seu distanciamento dos fundamentos do Concílio Vaticano II. Na discussão, enfocada sobretudo no ponto de vista da eclesiologia rahneriana, retoma importante entrevista do mesmo, no ano de sua morte, na qual aparece a sua preocupação com as chances futuras da Igreja, sobretudo na Europa Ocidental, a partir da qual abordam-se as relações entre Cristianismo e Igreja. As estratégias para a organização pastoral do mundo católico são a tônica desta reflexão. Para justificar suas posturas, o artigo termina com uma avaliação global de todo o conjunto teológico de Karl Rahner, redescobrindo nele os pilares mais fundamentais que justificam sua ortodoxia a serviço da fé cristã e católica, mas também a serviço da tomada de consciência de uma fé vivenciada e comprometida por parte da humanidade marcadamente secularizada.

PALAVRAS-CHAVE: teologia, cristianismo, Igreja, Concílio, pastoral.

\section{ABSTRACT:}

The article analyses negative criticisms against Rahner's theological views after his death with the intention of discrediting him and his role in Catholic orthodoxy by distancing him from the fundamentals of Vatican Council II. In the discussion, primarily focused on Rahner's ecclesiology, the article retakes a significant interview made the same year of Rahner's death. In this interview his concern for the Church's future chances, especially regarding Eastern Europe, embarking on relations between Christianity and Church. The strategies for world-wide organization of Catholic 
ministry predominate this reflection. Justifying its postures, the article concludes with a global evaluation of Rahner's theology, rediscovering the fundamental pillars which justify his orthodoxy at the service of the Christian and Catholic faith, but also at the service of a conscientious living of a committed faith on behalf of a notably secularized humanity.

KeY Words: theology, Christianity, Church, Council, pastoral

A primeira página do jornal vaticano "L'Osservatore Romano", de 25 de 1 fevereiro de 1985, estampava uma violentíssima crítica e um ataque quase que exterminador a todo o conjunto da obra do teólogo jesuíta alemão Karl Rahner, falecido 11 meses antes (a 30 de março de 1984).

Se, em vida, Rahner causou algumas perplexidades na crítica teológica eclesial, jamais alguém ou qualquer importante autoridade da Igreja havia excomungado o seu portentoso pensamento, como agora fazia um desconhecido estudioso dominicano, Ols Daniels. Todavia, não era o ataque em si que preocupava os comentaristas e estudiosos do pensamento rahneriano ou os eclesiólogos mais expressivos do momento, mas o fato de o referido artigo estar localizado na imprensa oficial da Igreja, quase significando uma tomada de posição vaticana sobre o grande teólogo católico, por muitos chamado de "o teólogo do século XX".

Muitas vozes se levantaram na época em defesa da teologia em questão, que ainda não havia sido totalmente absorvida, tal a sua densidade, seriedade e magnitude, mas que vinha iluminando os estudiosos e pensadores católicos na compreensão do homem do mundo moderno e da relação da Igreja com este homem e com este mundo. Rahner, desde o início do seu ministério teológico, impostou uma teologia que estivesse, acima de tudo, a serviço da salvação do homem no tempo em que ele se encontrava e que, sendo mais científica, se tornasse ainda e, por isso mesmo, muito mais kerigmática ${ }^{1}$.

O que se entendeu, na verdade, na época, quando, naquele ano de 1985, seria celebrado o vigésimo aniversário do encerramento do Concílio Vaticano II, foi que uma pequena minoria que tinha interpretado o Concílio numa visão restauradora, queria agora apresentar esta linha como a leitura intencional mais ortodoxa do Vaticano II. E aí, na perspectiva "restauracionista", enquadrava-se o ataque ao teólogo alemão e a alguns dos seus íntimos

\footnotetext{
${ }^{1}$ Ver as considerações do próprio Rahner quanto à cientificidade de uma tal teologia no artigo "Der gegenwärtige Stand der katholischen Theologie in Deutschland" in Kritisches Wort: Aktuelle Probleme in Kirche und Welt, Freiburg, 1970, pp. 11-13. As intuições de uma tal teologia e o programa de sua construção estão configurados nos Schriften zur Theologie I, Einsiedeln, 1984, pp. 9-47; no Lexikon für Theologie und Kirche I, p. 26 e no Schriften zur Theologie V, p. 7. No presente artigo a obra Schriften zur Theologie será citada com a abreviatura $S T$ seguida do volume em algarismo romano.
} 
colaboradores como H. Fries, entre outros ${ }^{2}$, como desviadores do sentido verdadeiro das considerações, intuições e proclamações conciliares, especialmente no que diz respeito à missão pastoral da Igreja no mundo, ao ecumenismo e a outras questões conciliares.

Sabe-se que a virada antropológica do Concílio Vaticano II, expressa em muitos dos seus Decretos e Declarações, sobretudo os de caráter mais missionário e ecumênico, e em suas Constituições, especialmente no que toca aos conceitos de Revelação, Graça e Igreja, deveu-se à ação indireta de Karl Rahner, graças à influência dos seus amigos, então Padres Conciliares, o Cardeal Franz König, arcebispo de Viena, e o legendário Cardeal Ottaviani.

Ainda hoje, uma importante ala de pensadores eclesiásticos pinta o Concílio como o maior desastre na história da Igreja desde a Reforma, e com um grande agravante em relação a esta, pois se na Reforma os hereges foram punidos, no Concílio os "hereges" ficaram e conquistaram o poder na Igreja. Aos olhos dos que assim pensam, Rahner é o "terror" da destruição da Igreja, ou, pelo menos, um teólogo inteligente que descobriu a dinamite que outros colocaram por sobre o tapete eclesial ${ }^{3}$. Todavia, Rahner nunca aspirou poder ou altos postos na Igreja, permanecendo nela como o "homem da reflexão". E como tal, colocou pilares tão sólidos na reflexão eclesial que, sem ser de direita ou de esquerda, abriu caminhos que foram tomados por outros bispos alemães e por seus próprios discípulos, como o Cardeal Ratzinger (hoje o homem da defesa da fé), de um lado, ou Hans Küng (excluído por esta mesma defesa), de outro, seguindo caminhos próprios, porém, agradecidos ao Mestre Rahner.

Contudo, quando na Igreja oficial se fala hoje de "interpretação autêntica" do Vaticano II, entende-se uma contraposição a todos os conseqüentes desdobramentos teológicos inovadores que apresentam uma ruptura com o passado ${ }^{4}$, particularmente com os Concílios de Trento (o da contra-Reforma, no século XVI) e o Vaticano I (o da infalibilidade pessoal do Papa, no século XIX). E aqui toda a obra do Rahner entra como a mentora ou a raiz provocativa destes desdobramentos não ortodoxos. Lembro-me de um professor de Cristologia, na Pontifícia Universidade Gregoriana, em Roma ${ }^{5}$,

${ }^{2}$ Importante discípulo e colaborador de Karl Rahner na coordenação e publicação de obras de tipo enciclopédico, como o Handbuch theologischer Grundbegriffe, em 2 volumes, publicado em München, nos anos 1962-1963, e co-autor de outras como Einigung der Kirchen - reale Möglichkeit, Freiburg, 1983.

${ }^{3}$ Cf. o recente artigo do holandês Pieter van der VEN intitulado "De Kunst van goddienstig én menswaardig".

${ }^{4}$ Ver entrevista de Giulio GIRARDI concedida à Revista Adista (Roma) de 15 de maio de 1985, pp. 11-13, com o título "Nella Ristaurazione Vaticana ocorreva sconfessare Rahner".

${ }^{5}$ Ver J. GALOT, Cristo Contestato, Firenze: Libreria Editrice Fiorentina, 1970. 
que, ao analisar as cristologias do século $X X$, apontava os desvios doutrinários de cada uma, levantando um conjunto de maioria não ortodoxa, para depois, sem ter caracterizado da mesma forma a cristologia rahneriana, concluir que esta era o ponto de partida para todas as heresias desenvolvidas posteriormente pelos outros cristólogos. Mostrava assim a teologia rahneriana como um pensamento de raiz perigosa, que ao se desenvolver em outros terrenos, proporcionava os mais absurdos desvios teológicos.

Isto pareceu ainda mais ousado quando, pouco tempo antes de morrer, Rahner escreveu uma carta aos bispos peruanos tomando corajosa defesa da teologia latino-americana, por ocasião de um processo a um de seus teólogos ${ }^{6}$. Na carta, ele estava convencido da importância do pluralismo teológico na Igreja, pelo qual não se concebe a dominação desse ou daquele teólogo, e considerava também que a elaboração da reflexão teológica está constantemente sujeita a desacertos 7 . Por um lado, dizia ele, "a teologia da libertação está consciente do seu significado limitado dentro da globalidade da teologia católica" e, por outro lado, "ela é também consciente de que a voz dos pobres deve ser escutada no contexto da Igreja latino-americana". Isto significava, para Rahner, que uma teologia que está a serviço da evangelização concreta nunca pode prescindir do contexto cultural e social da evangelização, para que esta seja eficaz na situação na qual vive o seu destinatário. Afirmava também, legitimando o método de reflexão da teologia da libertação, que as ciências sociais não podem ser norma para a teologia, pois esta se baseia em Jesus Cristo, no Evangelho e no ensinamento da Igreja. Porém, "não se pode fazer teologia eficaz sem levar em conta as ciências profanas". Com certeza, tomadas de posição desta natureza colocavam o teólogo católico Karl Rahner sob a mira do controle ortodoxo.

Esta tentativa de desacreditar Rahner depois de sua morte, quando ele já não pode mais se defender em seus escritos e preleções, tornou-se, ao que parece, uma empresa importante para alguns pensadores oficiais e atingiu também o próprio Cardeal Ratzinger, que se configura como antigo colaborador e amigo de Rahner, membro ele também do grupo dos teólogos progressistas que assessoraram e ladearam os episcopados da Alemanha e da França no seu intento de desarmar os esquemas preparados pela comissão teológica pré-conciliar. Encarregados pelo Cardeal König, Rahner e Ratzinger elaboraram juntos, nas primeiras semanas do Concílio, um projeto alternativo que, se depois não foi adotado, pelo menos contribuiu

${ }^{6}$ Quinze dias antes de sua morte, exatamente no dia 16 de março de 1984, K. Rahner escreveu uma carta ao cardeal Juan Landázuri Ricketts, de Lima, sobre a teologia da libertação e especialmente sobre o trabalho do teólogo Gustavo Gutiérrez, que, na época, era avaliado pelo "Santo Ofício". A carta será aqui citada na sua versão espanhola, publicada pela revista Vida Nueva (Madrid), n. 1325-1426 (21-28 de abril de 19884), p. 51.

${ }^{7}$ Cf. L. LAVALL, $O$ Mistério Santo: "Deus Pai" na Teologia de Karl Rahner, São Paulo: Loyola, 1987, pp. 163-169. 
imensamente para convencer os Padres Conciliares sobre a necessidade de rejeitar e modificar os esquemas preparatórios e a teologia neles expressa. Durante todo o período conciliar, continuou a colaboração intensa entre os dois $^{8}$, de tal modo que não fica muito fácil para Ratzinger obscurecer a figura de Rahner, uma vez que dele conheceu a excepcional qualidade intelectual e teológica, reconhecida unanimemente por todos, até mesmo pelo não suspeito teólogo Urs von Balthasar, admirado e exaltado até hoje pelo Cardeal Prefeito da Congregação para a Doutrina da Fé9.

Ratzinger, mais do que ninguém, conhece a ortodoxia da teologia rahneriana, que nunca foi seriamente contestada depois do Concílio. Continuamente se entrelaçam, no seu pensamento, a abertura ao mundo moderno e a contínua meditação da tradição cristã patrística e escolástica. Por isso mesmo, a Santa Sé o nomeou membro da Comissão Teológica Internacional e o próprio Joseph Ratzinger reconheceu a importância do seu trabalho como de uma inesquecível fonte de inspiração para a Teologia ${ }^{10}$, quando do lançamento do livro Grundkurs des Glaubens (Curso Fundamental para a Fé) em $1978^{11}$.

Hoje em dia, vivemos na Igreja duas tendências muito claras com relação à teologia: ou o dogma absoluto, de um lado, ou o relativismo de uma verdade inconsistente, de outro. Quando nos aprofundamos no pensamento rahneriano, encontramos um edifício teológico que vive permanentemente de uma forte tensão interna. É a tensão entre a verdade e a pluriformidade, entre o dogma e a relatividade, entre a mística e a ética, entre a oração e o trabalho, entre a espiritualidade e o engajamento. A teologia rahneriana, classificada como transcendental, entende que só pie-

${ }^{8}$ Rahner e Ratzinger publicam juntos alguns volumes sobre temas pertinentes. Em 1961, Episkopat und Primat, em 1965, Offenbarung und Überlieferung, fora as colaborações de Ratzinger no Lexikon für Theologie und Kirche, coordenado por Karl Rahner, sobretudo nos 3 volumes complementares que abrigam idéias e textos conciliares.

${ }^{9}$ Nos inícios de junho de 1985, participei de uma conferência do Cardeal Ratzinger na aula magna da Academia Alfonsiana, em Roma, na qual o Cardeal Prefeito apontava os verdadeiros mestres da fé da teologia católica, evidenciando muito a figura e o pensamento de Urs von Balthasar, entre poucos. Ao final da palestra, um participante perguntou-lhe porque não considerava na lista também o Pe. Rahner, uma vez que eles tinham muitas obras e intuições importantes em comum, e que eram fundamentos de espiritualidade e de fé. A resposta foi a seguinte: "Meus escritos com Karl Rahner foram coisas de juventude".

10 "Um grande livro. Devemos ser reconhecidos a Rahner por ter elaborado, como fruto de suas pesquisas, esta síntese imponente, que permanecerá como uma fonte de inspiração quando grande parte da produção teológica for esquecida." (J. RATZINGER para a Theologische Revue de Münster, citado em Adista (Roma) 15 de maio de 1985, pp. 12-13.

${ }^{11}$ K. RAHNER, Grundkurs des Glaubens: Einführung in den Begriff des Christentums, Freiburg, 1976 (tradução brasileira: Curso Fundamental da Fé: Introdução ao conceito de cristianismo, São Paulo: Paulinas, 1989). Obra publicada em quase todos os idiomas da teologia católica hoje. 
dade e mística anestesiam o cristianismo e debilitam sua força histórica. E só ética e pluriformidade esvaziam o cristianismo e o desenraízam do seu mistério fundamental - a autocomunicação de Deus em Jesus Cristo para elevar o homem à contemplação do Amor absoluto. Nesta tensão, Rahner jamais vai proclamar o dogma absoluto e nem vai relativizar a verdade, construindo um paradigma teológico da convivência dialética entre a origem eterna e substancial da fé no mistério infinito e eterno de Deus Pai e a resposta histórica e circunstancial do homem finito e temporal, aberto à possibilidade indiscutível de Deus. Portanto teologia e história, mistério e fato, mística e realidade sustentam a construção rahneriana. E isso favorece à incredulidade pós-moderna a ver em Rahner reflexões grandiosas e até absolutas enquanto encaminham para a busca de um sentido e de um caminho para a verdade, sem nenhuma outra pretensão maior ${ }^{12}$. Se seus escritos não se tornaram popularíssimos, a compreensão do mistério do ser humano e suas questões implicadas no mistério de Deus tornou-se uma das filigranas da teologia contemporânea.

No crepúsculo de sessenta anos de magistério teológico, ele mesmo se questionava sobre o valor da missão empreendida na vida e se perguntava em que teriam os seus livros eruditos contribuído para que o homem do seu tempo pudesse conhecer mais honestamente a Deus e assim experimentá-lo. É aí que Rahner descobre a pobreza do labor teológico e a importância do papel do poeta na comunicação do mistério de Deus, pois o poeta lida com uma palavra mais originária, menos desprovida de conceitos e limitações, uma palavra mais aberta e mais abrangente porque menos definida, mais sentida e experimentada, menos formal e mais vivencial. Uma palavra desprovida de contornos, que nem o teólogo e nem o sacerdote pregador conseguem pronunciar: a palavra não conceituada, que melhor envolve o indizível do mistério ${ }^{13}$. Constatando esta situação, Rahner reconhecia que não tinha este dom (e de fato, sabia que os seus escritos chegavam a ser incompreensíveis de tão densos de conceitos e elaborações racionais), o dom da poesia, que ele acreditava ser também um dos dons do Espírito Santo, embora não nomeado no capítulo 12 da carta aos Coríntios. E por isso dizia que a Igreja também necessita dos poetas, mesmo dos que estão fora de seus muros, para melhor dizer o que ela não consegue com seus conceitos e formulações teológicas. Todavia, se ele não era poeta, não lhe faltou outro dom, este sim muito importante e genuinamente cristão, o da humildade, para reconhecer o seu próprio limite ${ }^{14}$.

\footnotetext{
${ }^{12}$ São quase 2.000 artigos reunidos, em sua maioria, nos famosos 16 volumes dos Schriften zur Theologie, entre outros.

${ }^{13}$ Ver a meditação sobre a palavra "Deus" no Curso Fundamental da Fé, pp. 60-69 e L. LAVALL, op. cit., pp. 324-325.

${ }^{14}$ Cf. P. van der VEN no artigo citado acima.
} 


\section{Teologia a serviço da fé}

O pensamento de Rahner é complexo, sem dúvida, porque exige a fadiga da conceitualização, mas encontra o seu equilíbrio no interior das grandes intuições que habitam toda a sua obra. Tirando o homem de um idealismo puramente platônico e jogando-o na existência e na história, como o fez Heidegger, todo o mistério do homem é um apelo a Deus e a uma salvação que vem de Deus. Todavia, a "nostalgia" de Deus, escondida no modo de considerar o homem, é entendida por Rahner, na sua significação mais religiosa, através da análise formal do espírito humano, segundo a metafísica do conhecimento. Toda a riqueza da argumentação, sendo meditada no contexto da experiência da graça, permite à teologia rahneriana encontrarse com a mais rica tradição espiritual e mística do cristianismo, transformando-o numa mistagogia verdadeira e própria, de tal modo que não apenas a mística se caracterize como sustentáculo do seu sistema teológico, mas a própria teologia se radicaliza em termos de experiência religiosa.

Se, por um lado, a sua teologia se caracteriza por uma forte antropologia ${ }^{15}$, não se pode esquecer, por outro lado, que é à luz da revelação cristã mais explícita que Rahner põe os fundamentos da sua antropologia ${ }^{16}$. Ele se refere sempre ao fato histórico cristão para fundamentar os passos decisivos da sua reflexão teológica. Tal referência ilumina, seja o caráter histórico da revelação de Cristo e do cristianismo em geral, seja a condição inevitável de toda a teologia que é a sua ligação constante com a tradição.

Caracterizada por uma consciência viva da situação dada, da realidade mais profunda do homem e da problemática hodierna concernente ao discurso da fé, suscitada pela reflexão contemporânea, toda a teologia rahneriana é marcada por um caráter profundamente missionário, o que leva a pensar que Rahner ainda será descoberto pela teologia, apesar de todas as críticas e revisões que foram propostas e que foram por ele aceitas, e por aqueles que hoje se interessam pela honestidade intelectual da fé, num mundo que quer fazer teologia depois do pensamento de Descartes, Kant, Hegel e Heidegger, de um lado, e Freud, Feuerbach, Marx, Nietzsche e Sartre, de outro lado.

${ }^{15}$ Ver recente artigo de A. MARCHESI, "Da antropologia à filosofia da Religião: o horizonte transcendente natural do homem" in L'Osservatore Romano' (edição portuguesa) n. 14 (5 de abril de 2003) 9-10, sobre uma interessante convergência dos itinerários especulativos de Santo Tomás, Karl Rahner e J. Alfaro apresentada no livro da professora de Antropologia e de Filosofia da Religião na Pontifícia Universidade Gregoriana de Roma, G. SALATIELLO, O último horizonte: Da antropologia à Filosofia da Religião. ${ }^{16}$ Como Santo Agostinho, o Santo Doutor, o mérito de Karl Rahner é o de não ter considerado Deus como Verdade abstrata, mas como um Ser concreto, como uma "Pessoa" que se insere nos acontecimentos sem violentar a liberdade humana. Ver artigo de D. PANTANO, "Uma visão antropológica da história da salvação em 'De Civitate Dei', obra prima de Santo Agostinho" in L'Osservatore Romano (edição portuguesa) n. 37 (13 de setembro de 2003) 13-14. 
Em todo caso, cabe aqui recordar que Rahner propõe a sua como uma teologia, mas não como toda a teologia. Seus limites e fraquezas estão presentes, de modo que, mesmo aceitando uma base assim tão sólida, o próprio tempo se encarregará de criticar, corrigir e aprimorar as afirmações particulares de Rahner. Por enquanto, são importantes o conjunto do seu projeto e a sua realização global ${ }^{17}$.

Ao contrário do que parece, afirma o Pe. Alfredo Marranzini ${ }^{18}$ : "Karl Rahner é um defensor da tradição e tem um profundo sentido da ortodoxia e da fidelidade ao sentir da Igreja. Por isso, investiga as fontes bíblicas e patrísticas com atenção e técnica atualizada, enquanto analisa com paixão a imensa riqueza de pensamento que muitas vezes, sem saber ou sem a compreender bem, se esconde por detrás de formulações teológicas, litúrgicas ou mesmo ascéticas. Com uma atitude bastante reservada, que para algumas pessoas podia dar a falsa impressão de ser pouco respeitosa, ele analisa o valor dos conceitos, dos termos e das frases da teologia da Escolástica. As declarações do Magistério são interpretadas no seu contexto histórico com uma hermenêutica sutil e diferenciada, sempre animada pelo amor e pela submissão"

Deste nexo com as fontes e com a história do passado, continua Marranzini, "ele tira uma força de prontidão que lhe faz ver os problemas na realidade que lhes é própria, descobrir no nosso modo atual de pensar um esplendor desde há muito tempo esmorecido, despertar evidências, hoje, ocultadas e reavivar situações que pareciam estagnadas. Com habilidade, o teólogo alarga o âmbito desta questão, com uma série de interrogações, às quais nem sempre consegue dar uma resposta exaustiva. Não se trata de problematicismo, mas é um anseio consciente, que nunca consegue explorar suficientemente os tesouros da nossa fé transcendente" ${ }^{\prime \prime 19}$.

\section{Experiência de Deus e dignidade humana}

Neste empreendimento, Rahner era profundamente enraizado no pensamento de Santo Tomás de Aquino. Procurava ler Santo Tomás como discípulo de Santo Agostinho e compreendê-lo nos seus possíveis desdobramentos nos pensadores modernos e contemporâneos (Descartes, Kant, Hegel e Heidegger, sobretudo).

Daí nascia a questão fundamental que foi a base de sua reflexão em todos os campos do pensar teológico: "Como o homem moderno poderia se abrir

${ }^{17}$ Cf. L. LAVALL, op. cit., pp. 316-317.

18 A. MARRANZINI, "Teologia do Coração de Jesus: Considerações sobre um livro de Karl Rahner" in L'Osservatore Romano n.40 (4 de outubro de 2003) 12.

${ }^{19}$ Ibidem. 
à Revelação Divina, ou mesmo tornar-se ouvinte da Palavra, entendida como Revelação ?"20

Esta questão se desdobra numa segunda formulação: "Como a Igreja consegue anunciar a Boa Nova confiada a ela, num mundo secularizado, agnóstico e pluralista?" Ou ainda: "Como a Igreja pode estar a serviço da Revelação Divina e da dignidade da criatura humana ao mesmo tempo?"21.

O itinerário aberto por Rahner procura, então, superar o extrinsecismo da revelação nos confrontos da existência humana, típico da apologética clássica. Ele mostra que fundar a própria existência sobre uma palavra de Deus pronunciada na história não é algo arbitrário, mas corresponde à natureza mais verdadeira de tal existência. O homem é, pois, por natureza, o "ouvinte da palavra", que deve ter os seus ouvidos atentos à história, para encontrar nela a "palavra" que dá fundamento e ilumina a sua existência. Ele é aquele ente que, "em sua história, deve estar à escuta de uma eventual revelação histórica de Deus, que pode atingi-lo em forma de palavra humana".

Com isso, levando adiante o mérito da teologia platônico-cristã, a teologia rahneriana supera a tensão dialética da transcendência e da imanência da realidade divina, exatamente na experiência da santidade de Deus. Ou seja, ao mesmo tempo em que Deus se dá na realidade mais íntima, subjetiva e existencial do homem, enquanto o homem finito encontra no Deus infinito o seu fundamento e o seu abismo, a divina transcendência é considerada como a realidade absoluta, como o totalmente outro, como o Santo Mistério. E por causa desta síntese dialética, a própria profissão de fé do homem não pode se dar como uma simples teologia gnosiológico-ontológica. Deve se dar como resposta de fé que tem seu fundamento na realidade salvífica expressa pela revelação bíblica, que, por sua vez, mesmo sendo a palavra humana com a qual Deus se revelou na história, enquanto palavra de Deus não pode dizer algo diferente do que Ele seja na realidade mais própria e verdadeira: Mistério. Daí, mesmo tendo sua gênese numa reflexão gnosiológico-ontológica, o conceito de Mistério na teologia rahneriana apresenta uma praticidade kerigmática, pois em vez de salientar a preocupação de saber o que é Deus, procura saber como Deus, salvando-nos, se revela a nós. É, pois, um mistério de ordem salvífica e não de ordem lógica ${ }^{22}$.

Quando, finalmente, o homem, numa fórmula teológica, explicita a sua profissão de fé no Mistério que é Deus, ele fala realmente de Deus como o horizonte inaferrável da transcendência humana. "Se pensamos que nesta

\footnotetext{
${ }^{20}$ Este é o eixo fundamental da sua obra clássica Hörer des Wortes: Zur Grundlegung einer Religionsphilosophie, München, 1941.

${ }^{21}$ Este é o eixo fundamental da sua outra e primeira grande obra clássica Geist in Welt:. Zur Metaphysik der endlichen Erkenntnis bei Thomas von Aquin, Innsbruck, 1939.

${ }^{22}$ Cf. L. LAVALL, op. cit., pp. 314-315.
} 
formulação se indica o principium imprincipiatum, absolutamente nãooriginado, de toda a realidade pensável, então, neste horizonte inaferrável e sem origem da transcendência humana, é realmente nomeado o 'Pai' da doutrina cristã sobre a Trindade" ${ }^{\prime 23}$. É a este Deus que o homem tende e é Ele mesmo que se oferece ao homem em cada atuação da sua auto-experiência, em cada tematização objetiva do seu conhecimento e da sua liberdade, até culminar na experiência inefável do amor, enquanto vai tomando corpo a oração de Jesus: "Pai Justo, o mundo não te conheceu, mas eu te conheci e estes também conheceram que me enviaste. Eu lhes dei a conhecer o teu nome e lho darei a conhecer, a fim de que o amor com que me amaste esteja neles e eu neles" (Jo 17,25-26).

\section{Cristianismo e Igreja}

Para Rahner, esta radical experiência de Deus é esclarecida no cristianis$\mathrm{mo}^{24}$, que a define como graça e afirma que ela se impõe vitoriosamente e se autoproclama em Jesus Cristo ${ }^{25}$. Não se pode negar o valor universal do regime da encarnação que se evidencia no cristianismo. Todavia, a permanência histórica de um pluralismo de religiões ${ }^{26}$ "denuncia uma certa insuficiência da concretização atual do cristianismo, um certo caráter parcial, ao menos no que diz respeito ao seu revestimento cultural, não perfeitamente adequado à sua universalidade fundamental, pondo sérias interrogações sobre a salvação e a extensão do plano salvífico na história da pessoa e da humanidade" ${ }^{\prime 27}$.

Por isso mesmo, a relação entre o cristianismo e as outras religiões não coloca a antítese de que o bem está de um lado e o mal do outro. Ambigüidade e imperfeições se insinuam na concretude histórica de toda religião. O cristianismo, todavia, numa aproximação de perfeição com as outras religiões, apresenta-se como a etapa explícita final de um caminho religioso, segundo o modelo analógico da relação entre o Antigo e o Novo Testamento. As outras religiões são legítimas na medida em que representam etapas diversas na direção da definitividade escatológica do cristianismo, sem se poder dizer, todavia, quando se dá a obrigatoriedade da superação histórica de uma etapa ${ }^{28}$. Por isso, na sua essência mais autêntica, o

${ }^{23}$ K. RAHNER, Grundkurs des Glaubens, p. 440.

${ }^{24}$ Cf. $S T$ V, p. 16.

${ }^{25}$ Cf. $S T I X$, p. 175.

${ }^{26}$ Para uma fundamentação filosófica da tipologia das religiões, ver P. TILLICH, "Religionsphilosophie" in IDEM, Gesammelte Werke I, Stuttgart, 1959, p. 340ss.

${ }^{27}$ L. SARTORE, "Teologia delle religioni non-cristiane: la cosidetta 'linea Rahner" in Dizionario Teologico Interdisciplinare III, Torino: Marietti Editrice, p. 409.

${ }^{28}$ Ver o artigo "Über die Heilsbedeutung der nichtchristlichen Religionen" in ST XIII, pp. 341-350. 
cristianismo não se define como uma religião particular ao lado de outras, mas como a objetivação historicamente autêntica da experiência de Deus que, por força da universal vontade salvífica divina, existe em toda a parte como graça, enquanto Deus se participa a todos os homens ${ }^{29}$.

Disso resulta que "o dever do cristianismo é sobretudo o de chamar sempre a atenção sobre tal experiência de Deus, solicitar o homem a descobrila em si mesmo, a acolhê-la e a professá-la na sua objetivação verbal e social que, onde é pura e refere-se a Cristo como a seu sigilo, define exatamente o cristianismo" - religião da autocomunicação de Deus em Jesus Cristo.

Nesta ótica é que se deve entender a controvertida questão do "cristianismo anônimo" colocada por Rahner. Trata-se da situação da salvação fora da Igreja, uma vez que a vontade salvífica de Deus é universal e a graça é oferta absoluta da autocomunicação divina a um homem também absolutamente livre na resposta e tematização explícita desta oferta. De fato, para o conjunto da teologia da graça, enquanto revelação e salvação, e de todo o sistema rahneriano, não cabe ao ser humano ou a qualquer instituição ou instância histórica, mesmo que seja a Igreja, decidir como, onde, quando e em quem Deus opera ou não a sua livre autodoação.

Num artigo em que Sesboüé discute as objeções mais fortes a esta questão na teologia rahneriana, procurando superar as questões terminológicas da expressão "cristianismo anônimo", o autor conclui: "Pode-se compreender Rahner em duas direções: uma, que foi, sem dúvida, a mais praticada, mas que é também a mais discutível, vê nele uma empresa de generosidade teológica ambígua, batizando todo homem de boa vontade, esvaziando o título de cristão; outra, que me parece a justa, descobre nele a preocupação em mostrar como todo homem é salvo por Cristo e por força da presença e da irradiação de sua graça na Igreja. Com efeito, quanto à possibilidade de salvação, a doutrina de Rahner não é mais otimista que a do Vaticano II, retomada hoje por todos os teólogos. Sua contribuição consiste em dar uma interpretação teologicamente fundamentada da universalidade do cristianismo, num mundo em que o número dos não-cristãos põe as mais graves questões tanto ao teólogo quanto ao apóstolo" ${ }^{130}$.

Para se entender o que realmente Rahner entende sobre a Igreja e a sua missão salvífica no mundo, como eco da eclesiologia do Vaticano II, é preciso voltar à sua noção cristológica de "símbolo". Parte-se do fato que a ação salvífica de Deus sobre o homem, desde o início até à sua realização, acontece mediante o símbolo em que Deus se revela e se comunica de maneira histórica e compreensível ${ }^{31}$. Exige-o a constituição unitária do ho-

${ }^{29}$ Cf. $S T I X$, p. 175.

${ }^{30}$ B. SESBOÜÉ, "Karl Rahner et les 'chrétiens anonymes"' in Études, 361/5 (1984) 521-535.

${ }^{31}$ Ver K. RAHNER, "A importância eterna da humanidade de Cristo para a nossa relação com Deus"; "Por uma teologia da Encarnação"; "A Cristologia dentro de uma compreensão evolutiva do mundo" in IDEM, Teologia e Antropologia, São Paulo: Paulinas, 1969, pp. 43-59, 61-84 e 85-134 respectivamente. 
mem, que é espírito encarnado ou "espírito no mundo" (Geist in Welt). Por isso, o corpo é símbolo da alma, dado que ela o informa, nele se realiza a si mesma, adquire consciência de si e se manifesta. Nesta unidade de símbolo e de realidade simbolizada, de corpo e de alma, os membros separadamente não são elementos que se unem uns aos outros apenas em nível material, mas são partes vitalmente unidas a todo o conjunto, embora naturalmente cada uma de maneira diferente.

Continuando daí e partindo da revelação, Karl Rahner lança o fundamento supremo e radical do símbolo real intrínseco na teologia do Verbo, no âmbito trinitário, e do Verbo na sua encarnação para a nossa salvação. Porém, o Verbo assume na sua Pessoa a nossa natureza humana e tornase o símbolo absoluto de Deus no mundo, sempre repleto da realidade simbolizada. Além de ser a presença e a revelação daquilo que Deus é em si mesmo, exprime o que Deus quis ser para o mundo, de maneira irrevogável e indelével.

Convencido, pois, de que não pode haver uma teologia que não tenha como sujeito o símbolo, Karl Rahner vê a Igreja como um sinal visível, autêntico e eficaz de Cristo morto e ressuscitado, sinal repleto da graça que o Redentor trouxe de maneira definitiva ao mundo. A Igreja é realmente distinta de Cristo, assim como nele a divindade é, na verdade, distinta da humanidade.

Porém, distinguir não significa separar. "Na Igreja existe uma profunda unidade entre esses dois aspectos diversos, mas na realidade inseparáveis. Cristo e a graça do Espírito Santo não devem ser procurados fora da Igreja. O Pai, mediante o Filho encarnado, morto, ressuscitado e operante, com o seu Espírito, comunica-nos a vida divina na Igreja e nos sacramentos, de maneira histórica e visível, ou seja, simbólica" ${ }^{\prime 32}$.

\section{4. “Inverno" na Igreja}

No dia do seu $80^{\circ}$ aniversário, em 5 de março de 1984, algumas semanas antes de sua morte, Rahner concedeu ao correspondente da editora Herder, David Seeber ${ }^{33}$ a última de suas entrevistas. O teor da entrevista revela uma visão da maturidade de quem durante sessenta anos pensou e repensou o mistério da Igreja, sua missão e presença no mundo, e mais ainda, acompanhando o desenvolvimento da sociedade do século XX, demonstrava uma inquietante preocupação pelas suas chances no século XXI.

\footnotetext{
${ }^{32}$ A. MARRAZINI, op. cit., p. 13.

${ }^{33}$ Da Herder Korrespondenz, edição de abril de 1984, pp. 165-171, publicada em tradução italiana na revista Il Regno (Bologna) 29 (1 $1^{\circ}$ de maio de 1984) 286-294, sob o título "L'inverno della Chiesa e le prospettive del Cristianesimo".
} 
Expressões fortes e idéias ousadas vão aparecendo na entrevista como em um testamento. Nada do que já não dissera em outros textos e conferências, mas agora quase que em forma de conselhos práticos sobre o modo de a Igreja fazer sentido na nova configuração do mundo e da sociedade, sem ficar esvaziando-se por jogar o tempo todo na defensiva contra a secularização.

Ainda que não se lembrando quem cunhou esta expressão, Rahner fala de um "inverno na Igreja" para definir o momento eclesial sobretudo da Europa ocidental. Não quer com isso falar da Igreja em geral e nem da impressão que a Igreja causa no mundo. Também não julga da mesma forma a situação da Igreja na América do Sul ou em certos países da África. Nestes continentes, Rahner via "um cristianismo em expansão e uma Igreja com um futuro glorioso", mesmo que futuramente correndo os riscos próprios do desenvolvimento sócio-tecnológico-cultural do Primeiro Mundo, como veremos adiante.

O inverno na Igreja européia se manifesta a partir de alguns dados como, por exemplo, a escassez de vocações, a falta de procura pelo batismo de crianças nas grandes cidades, a relatividade e a instabilidade do matrimônio entre os católicos, a quase inexistente procura pelos sacramentos em geral e a indiferença quanto à missa dominical em particular. A análise de Rahner procura entender que na Europa se presume a não coincidência entre eclesialidade e cristianismo. Não são a mesma coisa. "Existe um comportamento fundamental religioso que se exprime até numa certa responsabilidade moral diante da vida ou mesmo no respeito a Deus, mas as práticas religiosas específicas da Igreja como a missa aos domingos, a participação nos sacramentos e a freqüente observância da prescrições morais eclesiásticas são consideradas coisas sem importância e antiquadas" ${ }^{\prime 34}$. E é aí que Rahner sente que a Igreja fica o tempo todo na defensiva e não avança a sua reflexão científica na compreensão antropológica e ética do cristão que vive neste mundo.

Quais são as causas deste fenômeno? Segundo Rahner, as causas não são de tudo profanas, sociais e históricas, como se o quadro pudesse mudar a partir da boa vontade das pessoas e da intensificação dos apelos morais

\footnotetext{
${ }^{34}$ Veja análise de pesquisa recente sobre o Catolicismo no Brasil em CERIS, Desafios do catolicismo na cidade: Pesquisa em regiões metropolitanas brasileiras, São Paulo: Paulus, 2002, sobretudo quando mostra a posição dos católicos com relação a temas como aborto, contracepção, relações sexuais pré-matrimoniais, segundo casamento, homossexualismo, etc. Ver ainda R. PRANDI, "Busca da fé" in Folha de São Paulo de 26 de dezembro de 1999, retomado integralmente no volume 82 dos Estudos da CNBB, O itinerário da fé na iniciação cristã de adultos, São Paulo: Paulus, 2001 (cf. pp. 51-76: R. PRANDI, Religião, biografia e conversão: escolhas religiosas e mudanças de religião). Ver ainda L. AMARAL, Carnaval da alma: Comunidade, essência e sincretismo na Nova Era, Petrópolis: Vozes, 2000; P. SANCHIS (org.), Fiéis \& Cidadãos: Percursos de sincretismo no Brasil, Rio de Janeiro: EDUERJ, 2001 e os volumes 20 e 21 da revista Religião e Sociedade.
} 
por parte da Igreja. O quadro se coloca assim pela própria realidade da secularização, que também acabará chegando nos continentes emergentes. Mas nestes, diz Rahner, a Igreja pode tomar medidas preventivas, não apenas chegando junto às elites secularizadas, mas também ocupando-se das pessoas que vêm diretamente da base, como líderes, representantes ou animadores de pequenas comunidades ${ }^{35}$. Mesmo porque, segundo ele, não podemos e não devemos pensar que, num futuro próximo, teremos um grande número de pessoas como membros vivos e ativos da Igreja. "Devemos trabalhar intensamente e carregar um espírito de otimismo e interdependência para termos, pelo menos, um mínimo consistente de cristãos ativos que não sejam apenas uma minoria insignificante na socieda$\mathrm{de}^{\prime \prime}$. Por isso, é importante que a Igreja se preocupe com as classes dirigentes desta sociedade ${ }^{36}$.

Neste sentido, Rahner apresenta uma estratégia pastoral que parte da seguinte pergunta: "A Igreja é sábia quando insiste em manter ainda hoje o sistema de paróquias distribuídas em todo o território, ou não seria melhor criar oásis florescentes em meio a amplas zonas de deserto?" A imagem analógica questiona se não é melhor "usar um certa quantidade de água, que, inevitavelmente está para acabar, para criar um oásis em algum lugar, em vez de distribuí-la em todo o território, sem poder matar a sede em todo lugar". A mesma coisa ele quer dizer quando mostra que um bispo, em vez de formar um padre para que se torne um homem vivo e moderno e um cristão radical, para, então, enviá-lo a uma grande cidade, o manda para o mais perdido lugarejo do Tirol, que, bem ou mal, pode ser atendido pelos párocos vizinhos. Como entender isso numa postura de oásis florescentes?

A argumentação parte da consideração, típica da teologia rahneriana, de que a fé deve ser fruto de uma decisão pessoal sempre renovada. A fé é o lado humano da resposta e da aceitação da graça livremente oferecida em Cristo. Do ponto de vista teológico e histórico, a Igreja, desde as suas origens, sempre foi um pequeno grupo, porém orientado e finalizado a todo o mundo. Ora, a partir do momento em que, historicamente, ela se localiza no mundo inteiro, como uma igreja mundial, ela não é mais a expressão social de uma fé decididamente vivida, mas torna-se uma cristantade compacta e massificada, presente em todo lugar.

É importante observar nestas considerações que Rahner não quer, com isso, renunciar à religiosidade do povo católico em suas expressões mun-

\footnotetext{
${ }^{35} \mathrm{Na}$ realidade, o teólogo alemão tinha um olho em toda a Igreja e conhecia o que estava acontecendo como movimentos de vitalização na Igreja do $3^{\circ}$ Mundo.

${ }^{36}$ Creio que preocupações semelhantes já chegam em nossas igrejas e estão presentes na intenção e no objetivo das orientações gerais do documento $\mathrm{n}^{\circ} 72$ da CNBB, Projeto Nacional de Evangelização (2004-2007): Queremos Ver Jesus Caminho, Verdade e Vida, São Paulo: Paulinas, 2003.
} 
diais, enquanto cristandade, deixando as pessoas caminharem por conta própria na administração de sua fé, como também não quer negligenciar a possibilidade de um crescimento da Igreja a partir da base. O Vaticano II, segundo ele, tornou muito clara a compreensão eclesial a respeito da história da salvação: a divina vontade universal de salvação é quem faz a Igreja presente em toda parte, ainda que não exista a cristandade compactada em cada lugar. As "sementes do Verbo" é que estão plantadas em todo lugar. A Igreja nasce da resposta consciente e tematizada a esta oferta. Todavia, historicamente, de Santo Agostinho até o século XIX, o mundo não-cristão era considerado como uma "massa danada", diz ele. Até São Francisco Xavier pensava assim: "Se eu não salvar um homem que vive na Índia ou no Japão, ele estará perdido". Hoje, nenhum missionário vai ao Japão convencido de que aqueles a quem não atingir estarão perdidos.

Rahner não entende desqualificar a evangelização e nem dizer que não se deva evangelizar para que os homens sejam explicitamente cristãos. $\mathrm{O}$ realismo cristão nos faz esperar e confiar sem temor, pela sua própria vontade de salvação universal, que Deus ama concretamente muitos daqueles aos quais a Igreja não atinge em seu ministério evangelizador.

Por isso, é preciso criar comunidades vivas, inspiradas na radicalidade das comunidades primitivas da Igreja, com uma forte consciência de missão e de distinção do resto do mundo, sem, todavia, tornarem-se guetos isolados, que acabam "suscitando o calor do ninho sem aquecerem o resto do mundo". Às vezes, as comunidades cristãs se configuram como "vasilhas térmicas, que mantêm quente o que está dentro e deixam frio o lado de fora". Com mais esta outra imagem analógica, Rahner queria dizer que "a Igreja será sempre uma Igreja aberta, ou seja, não poderá ser feita de homens que não sabem comunicar com o resto do mundo, mas de homens que sabem conquistar o resto do mundo através de uma autêntica convicção cristã, sem todavia clericalizá-lo, seja de formas antigas ou novas". Entendo aqui um ponto de inspiração para a consciência missionária do atual Projeto quadrienal da CNBB, "Queremos ver Jesus, Caminho, Verdade e Vida" que pensa a missão a partir da convicção ativa dos evangelizados ou daqueles que já estão inseridos nas comunidades autenticamente cristãs, enquanto propositores da luz da fé para os distantes, os afastados, os excluídos, os indiferentes ou os desconhecedores do projeto salvífico de Jesus, à espera, quem sabe, de uma tomada de posição de fé também por parte destes $^{37}$, o que aliás é a linha de proposta do Decreto Ad Gentes do Vaticano II.

As comunidades eclesiais devem surgir e se organizar somente a partir da essência da mensagem cristã. Esse é um fundamento eclesiológico irrenunciável para o nosso teólogo. E quanto mais houver comunidades

${ }^{37}$ Cf. acima, nota 36 . 
deste gênero, tanto maior serão as suas possibilidades de constituir o início de uma Igreja novamente distribuída em todo o território. Uma pessoa que não tenha tanta cultura teológica ou mesmo religiosa, portanto dotada de um potencial religioso muito limitado, mas bem disposta ao cristianismo, se em vez de encontrar na cidade grande só paróquias, encontrasse uma comunidade cristã viva, estaria em muito melhores condições de vivenciar uma fé de melhor qualidade existencial. Diz ele: "Não defendo ideologicamente e nem de forma excludente que esta estrutura atual tenha que acabar. Defendo, sim, que a Igreja deveria empregar corretamente, nos justos lugares, o potencial de socialização religiosa que ainda tem e que se torna sempre menor. É isso que falta!"

A Igreja, nos últimos séculos, depois do Concílio de Trento, experimentou um reforço do aspecto jurídico de uma forma como jamais o fizera. A tendência a defender-se da secularização e do iluminismo moderno contribuiu para isso. Na Europa, ela se apoiou muito em movimentos de restauração, não se comportando ou não se considerando mais como promotora da história, mas como guardiã da continuidade. E assim fica difícil para ela acolher o novo, pois este terá primeiro que demonstrar ser uma coisa boa, mesmo se é bom por si mesmo.

Logicamente quando existe um cristianismo fundado em costumes e tradições, mas que permanece vivo enquanto cristianismo, deve ser mantido com todas as forças e levado adiante, pensa Rahner ${ }^{38}$. Porém, a Igreja precisa ter a coragem de adotar uma estratégia precisa para a sua ação, em vez de lançar-se em todas as frentes possíveis. Pois quando é assim, ela acaba falindo e frustrando o seu papel por não ter forças suficientes para evangelizar em todas as frentes abertas.

\section{Futurologia eclesial}

Segundo Karl Rahner, algo de extraordinário aconteceu no Concílio Vaticano II. A Igreja queria colocar-se diante da sociedade e da ciência contemporâneas com uma atitude corajosa, confiante e dinâmica. Por isso, teve que sentar, refletir sobre si mesma e limpar os seus óculos. Mas enquanto os limpava, não podia ver as coisas de maneira distinta clara e colorida. Só depois de limpas as lentes e bem colocadas diante dos olhos é que ela poderá enxergar bem. E para se ver com clareza a mudança é preciso paciência histórica.

Por isso torna-se necessária uma "futurologia eclesial" que afronte as alternativas de ação da Igreja no mundo de hoje. O novo Código de Direito

${ }^{38}$ Entrevista citada in Il Regno 29 (1984) 287. 
Canônico ${ }^{39}$, segundo o nosso teólogo, é simplesmente a edição revista do Código de Bento XV, e que era, justamente, o livro de Direito da Igreja Católica Romana presente quase que exclusivamente na Europa Ocidental. "A Igreja atual não poderá mais ser igual à Igreja européia que foi exportada para o Terceiro Mundo" 40 . Se tivesse sido pensado a partir de uma estratégia para o futuro, o Novo Código não seria feito deste jeito.

Para o futuro, a Igreja, bem como a Teologia, deveriam preocupar-se fortemente em clarear bastante para os homens que, não obstante a consciência contemporânea encontrar-se diante de problemas vastos e não sintetizáveis, eles podem, assim mesmo, viver com a confiança e a coragem de autênticos cristãos. Em outras palavras, precisam demonstrar que o cristianismo pode conviver bem com a síntese do humano, do científico e do sociológico, ainda que esta síntese hoje ainda não esteja feita em sua totalidade.

Diz Rahner: "Penso que, mesmo que possa exprimir-se eclesialmente em muitos modos, o cristianismo, em sua essência, não é apenas um aspecto particular da realidade em concorrência com outros aspectos da mesma realidade. Ele é a aceitação, pela fé, da unidade de todas as realidades, não obstante a impossibilidade de integrar todos os seus aspectos". Esta unidade de todas as realidades integradas no cristianismo não é feita pelo homem, mas é fundada na própria revelação de Deus. A fé na revelação feita por Deus está para além de toda outra visão de mundo que faz de uma verdade qualquer o seu deus.

Isso faz com que a Igreja, mais do que nunca, assuma o dever de apresentar decididamente a essência da mensagem cristã, evitando de qualquer forma ceder a um humanismo deslavado e mesclado de "paganismo". Até mesmo o teólogo, evitando fazer pregações durante suas aulas, deve demonstrar com a sua vida que crê verdadeiramente e que age segundo esta fé, conseguindo dar significado à sua vida na referência ao Cristo Crucificado e Ressuscitado. Não se pode obscurecer a radicalidade única e original da mensagem cristã. Se esta fosse mostrada de modo vivo e claro, não seriam mais necessárias tantas seguranças clericais fundadas na burocracia sufocante e no Direito Canônico.

"Quando se tiver coragem de agir e tomar o cristianismo na sua radicalidade, sem deixar que as questões jurídicas, institucionais e políticoeclesiais apareçam como questões fundamentais, obscurecendo a verdadeira mensagem, estará então aberto o caminho para a 'primavera' na Igre-

${ }^{39}$ CÓDIGO DE DIREITO CANÔNICO, tradução oficial da Conferência Nacional dos Bispos do Brasil com notas e comentários do Pe. Jesús S. Hortal, SJ, São Paulo: Loyola, 1983.

${ }^{40}$ Entrevista citada em Il Regno, p. 288.

${ }^{41}$ Idem, p. 293. 
ja"41. Todavia, conclui Rahner, não se sabe ainda claramente como atingir a necessária intensidade da conviç̧ão cristã fundamental. Mas a esperança cristã nos leva a pensar que este tempo de inverno não é prenúncio de uma morte definitiva. Talvez seja mais um estímulo para que, "durante o inverno, cada um, naquilo que lhe é possível, atue com coragem e decisão para dar maior vida àquilo que é a essência da fé, e, assim, fazendo-a brilhar sobre o mundo, torne a Igreja o sinal sacramental da salvação do mundo".

\section{Reflexões conclusivas}

Na berlinda pós-conciliar, especialmente quando pensa sobre o Cristianismo e a Igreja do futuro, Rahner, na verdade, é um sistemático neotomista moderno, centrado nas formulações essenciais do Magistério, que tentou organizar uma consciência científica do dado da fé. Imbuído do dever de trabalhar uma hermenêutica das formulações doutrinárias da fé, soube construir uma síntese do novo científico com o tradicional revelado e construir um edifício teológico que, partindo dos grandes princípios e fundamentos do cristianismo, faz permanentemente a síntese entre sistemática e exegese, entre teologia e kerigma, entre reflexão e ação pastoral ${ }^{42}$.

Em todo o desenrolar do seu trabalho teológico, Rahner tem bastante consciência de ser um homem de fé, e de fé católica. A teologia para ele só se justifica enquanto se coloca a serviço desta mesma fé, que, nascida da experiência bíblica, foi veiculada, durante os séculos, pela tradição e custodiada pelo magistério da Igreja ${ }^{43}$, que a propõe em formulações ou definições dogmáticas.

\section{Teologia e Dogma}

Ora, toda definição dogmática é não somente ponto de chegada, mas também ponto de partida do processo vivo da fé, para uma compreensão crescente do seu conteúdo, pois consiste numa formulação humana histori-

\footnotetext{
${ }^{42}$ Ver análise detalhada deste aspecto no conjunto da teologia rahneriana em L. LAVALL, op. cit., pp. 31-76.

${ }^{43}$ A propósito do magistério, ver os artigos: K. RAHNER, "Lehramt" in Lexikon für Theologie und Kirche VI, pp. 884-890; M. LOEHRERE, "Träger der Vermittlung" in Mysterium Salutis I, pp. 545-587; A. I. DESCAMPS, "Théologie et Magistère" in Ephemerides Theologicae Lovanienses 52 (1976) 82-133; COMISSIO THEOLOGICA INTERNATIONALIS, "Theses de magisterii ecclesiastici et theologiae ad invicem relatione" in Gregorianum (Roma) 57 (1976) 549-563 e J. ALFARO, "La teologia di fronte al magistero" in R. LATOURELLE e G. O'COLLINS (edit.), Problemi e prospettive di teologia fondamentale, Brescia, 1980, pp. 413-432.
} 
camente condicionada pelo contexto cultural e lingüístico do seu tempo ${ }^{44}$. Assim, a fé, na busca da própria autocompreensão, não pode prescindir de interpretar o conteúdo dos dogmas, isto é, de tornar-se teologia (fides quaerens intellectum), cuja tarefa própria consiste na compreensão-interpretação "científica" (consciente do seu método) das formulações do magistério.

Cabe, pois, ao teólogo delimitar o exato sentido originário do texto definido, integrar o seu conteúdo na Escritura e na Tradição, e compreender e expressar em pensamento e linguagem atuais, abertos ao futuro da fé, as definições que, na fé, aceitou do magistério ${ }^{45}$, como interpretação autêntica da revelação ${ }^{46}$.

Nesta linha, a teologia rahneriana procura refletir sobre problemas que, de outro modo, não teriam respostas suficientes. O que conta, porém, não são os enunciados particulares e concretos da sua teologia, mas a força de tensão interior capaz de sustentar vivas oposições ou contraditórias situações, tornando-as fecundas. Manter a unidade e a diferença entre tradição e interpretação, entre a "substância" da fé recebida em herança e a reflexão crítica, entre o conhecimento histórico do passado e o presente que nos

${ }^{44} \mathrm{O}$ dogma se expressa necessariamente numa linguagem concreta e em determinados conceitos de cultura, de modo que, em outras circunstâncias, teria que assumir outras formas de expressão, o que não implica deficiência nos resultados, mas contingência das linhas de crescimento que direcionam o progresso (que não se confunde como contingência do realmente obtido e desenvolvido). Cf. Z. ALSZEGHY, Lo sviluppo dogmatico (ad usum privatum, PUG), Roma, 1982, p. 4. Tudo o que é definido pela Igreja (última etapa do processo de evolução do dogma) é absolutamente irrevogável (cf. $D S$ 2145). Por outro lado, a própria infalibilidade impede o uso de conceitos inaptos. Por isso quando um Concílio não apenas usa, mas também sanciona determinados conceitos, não é lícito prescindir deles (cf. DS 2311). É respondendo a essa aptidão dos conceitos para todos os tempos que o teólogo trabalha, em cada tempo, a sua interpretação de conteúdo e aprofunda a sua compreensão.

${ }^{45}$ Se o Vaticano I clarificou que o conteúdo do magistério deve ser aceito, em última análise, como "revelado por Deus" (divinitus revelata: DS 3011), o Vaticano II afirma, de modo explícito, que o magistério, nas suas definições, deve proceder em conformidade com a revelação divina ("cui omnes stare et conformari tenentur": ( $L G 25$ in AAS 57 [1965]: 31) e que a função de interpretar autenticamente a Palavra de Deus (escrita e transmitida) corresponde exclusivamente ao magistério vivo da Igreja, não estando este magistério acima da Palavra de Deus, mas a serviço da mesma ( $D V 10$ in AAS 58 [1966]: 822), em atitude de fé ("pie audit") e de fidelidade no guardar e no expor o conteúdo revelado, propondo-o como revelado por Deus. Nota-se perfeitamente nos textos do Vaticano II que as definições do magistério reconhecem a transcendência da Palavra de Deus e a sua relatividade diante dela: define-se porque foi revelado, e não vice-versa (cf. J. ALFARO, op. cit., pp. 422-424).

${ }^{46}$ Além de transmitir, a Igreja deve explicar e declarar fielmente o conteúdo do depósito revelado (cf. $D S 1800,1936$ ) em todos os tempos e a todos os povos, o que exige mais que a simples repetição de uma fórmula morta, e leva necessariamente a uma inteligência crescente da mensagem, que tem seu cume na proclamação infalível do seu conteúdo pelo magistério, quando se chaga à sua maior inteligência (cf. $D S$ 1792).

${ }^{47}$ Cf. K. LEHMANN, "Karl Rahner" in H. VORGRIMLER / R. VANDER GUCHT (ed.), Bilanz der Theologie im 20. Jahrhundert (IV): Bahnbrechende Theologen, Freiburg, 1970 (citado aqui na tradução italiana: Bilancio della teologia del XX secolo, vol. IV, Roma, 1972, p. 182). 
atormenta, é uma propriedade essencial e rara no pensamento de Rahner ${ }^{47}$. Tem em comum com Santo Tomás o modo em que faz emergir o significado e o peso das afirmações da teologia eclesiástica, para que elas falem para nós em toda a sua amplitude e profundidade, salvando-as assim para nós e nosso tempo. Nesse empreendimento teológico, ele vai à frente só na medida em que a tradição permite e, por isso, quando dá um passo, leva consigo toda a teologia e a consciência eclesial. Sabe, sem ser inconseqüente, ver as coisas na realidade patente, sabe despertar as evidências que estão adormecidas no ensinamento do magistério e dar-lhes nova colaboração e interesse ${ }^{48}$, numa perfeita articulação do novo com o tradicional, do existencialismo com o tomismo, da teologia com o querigma, da sistemática com a exegese.

Entretanto, muito mais do que o confronto temático com as idéias modernas, o que garante a modernidade da teologia é o fato de o teólogo pertencer à sua época (trazendo em si os traços positivos e negativos do seu tempo, que já implica a aquisição da filosofia por parte da teologia) e o fato de trazer a si mesmo (enquanto homem que faz teologia) na própria interrogação teológica ${ }^{49}$.

É de se notar, porém, que ele partilha fielmente o senso da tradição e a devoção ao ensinamento da Igreja, respeita a piedade e a disciplina dos fiéis e segue as estipulações do Direito. Coloca a Sagrada Escritura no centro do seu horizonte mental e busca continuamente uma sólida fundamentação do seu pensamento na patrística e em Santo Tomás. E, fiel a este último, procura apresentar e justificar a mensagem cristã, de forma a responder melhor à estrutura mental do homem contemporâneo.

\section{Síntese do novo com o tradicional}

Com efeito, a fidelidade à tradição não implica apenas uma aceitação do status quo. Rahner aplica, portanto, o método clássico da qualificação teológica para desenvolver, de modo crítico, uma sensibilidade interior que possa apreciar cada momento da tradição, reconhecendo-a bastante instrutiva para iluminar a reflexão atual da fé, ampliando-a ou até mesmo corrigindo-a, uma vez que as definições que derivam de uma tal reflexão são normalmente insuficientes. Existe, pois, em sua teologia, um esforço criativo caracterizado pela confiança numa tradição de fé já purificada, mas que é, ao mesmo tempo, uma confiança armada de crítica que permite

${ }^{48}$ Cf. J.B. METZ, "Karl Rahner" in Lessico dei teologi del secolo XX. Mysterium salutis - Suplemento, vol. XII, Brescia, 1978, p. 534.

${ }^{49}$ É importante a consideração sobre o homem que Rahner faz no artigo "Grundsätzliche Überlegungen zur Anthropologie und Protologie im Rahmen der Theologie" in Mysterium Salutis II, pp. 406-497. Cf. a mesma idéia em J. B. METZ, Christliche Anthropozentrik, Munique, 1962, p. 52ss. 
descobrir o modo de transmissão dos conhecimentos da fé através da história da Igreja. Esta criatividade é impulsionada, em última análise, pela convicção de que "aquilo que é apenas transmitido, se não é depois reelaborado por um esforço pessoal do teólogo, está destinado a perecer como o maná" ${ }^{50}$.

Neste esforço criativo, o "novo" não entra por mera modernidade, mas por fidelidade ao próprio início histórico, pois ele acredita que o futuro da teologia só se encontra partindo de onde ela deriva; e o "traço conservador" é exatamente a sua ligação à história e à fé da Igreja. Assim, a sua teologia não é um repetir de maneira estéril a tradição da fé, mas um assumir a tradição na situação presente, buscando superar, para mais além, a sua compreensão, numa perfeita síntese entre o novo e o tradicional.

Em Rahner, a aplicabilidade da filosofia e também da filosofia de Santo Tomás aparece não como foi fixada nos textos escolásticos, mas como se apresenta a quem sabe desenvolvê-la segundo as instâncias contidas no pensamento filosófico moderno e em conformidade com a autocompreensão que o homem, hoje, tem de si mesmo. Esta compreensão, em vez de cosmocêntrica, é sobretudo antropocêntrica. Podemos assim dizer que a presença tomista na teologia rahneriana não é descoberta por uma análise feita de fora por outros observadores do seu pensamento. Ela é intencionalmente consciente para o próprio autor, para quem Santo Tomás merece ocupar, ainda hoje, uma posição privilegiada na teologia católica, com o direito de ser chamado de "mestre" e "doctor communis". Isto não somente porque sob este ou aquele aspecto explicou os mistérios melhor que outros teólogos, mas principalmente porque adotou, em toda a sua teologia, uma forma de pensar (Denkform), um esquema mental e uma perspectiva atual, moderna, que é a forma antropocêntrica de pensar.

O grande mérito do teólogo alemão consiste exatamente em fazer emergir esta esquecida dimensão do pensamento tomista. Assim, o neotomismo rahneriano não fez outra coisa senão libertar a teologia da posição de "objetivismo", no qual a dogmática eclesiástica estava totalmente aprisionada, para levá-la a um subjetivismo antropológico, isto é, a um fazer teologia a partir da própria subjetividade humana, enfocada não só como fim, mas também como ambiente e como pressuposto do seu discurso.

\section{Relações mútuas entre Sistemática e Exegese, Teologia e Querigma}

Finalmente, cabe ainda destacar aqui um ponto bastante característico do modo rahneriano de fazer teologia sistemática. Segundo ele, a sistemática

${ }^{50}$ Cf. ST I, p. 19. 
deve, antes de mais nada, saber manejar com destreza os instrumentos exegéticos e aprender a reconhecer o peso das suas considerações e dos problemas colocados por eles, não ignorando-os, como se eles não dissessem respeito ao objeto da sua reflexão. Do contrário, a sistemática seria juíza de suas próprias questões e com muito pouca precisão. É claro que a sistemática e a exegese (incluindo também a teologia bíblica) são ciências bem distintas e não se desconhece mais a dificuldade que uma ciência tem em conhecer outra ciência, ainda que o tanto necessário para se falar dela com competência, dada a grande extensão de uma ciência moderna e a complicada mecânica dos seus métodos.

Em todo caso, a teologia bíblica constitui um elemento intrínseco da própria dogmática, um elemento absolutamente distinto e único e não apenas um elemento ao lado de outros elementos da "teologia histórica". Enquanto ciência específica, a sistemática deverá representar a verdadeira mediação entre a exegese e a dogmática, dando à exegese uma função muito importante a desenvolver na teologia, particularmente na teologia fundamental, e levando a dogmática a exigir muito do trabalho exegético ${ }^{51}$.

Nesta interação mútua, sistemática e exegese se colocarão eficazmente a serviço do magistério e este poderá ter sua segurança científica nos resultados da reflexão proposta pela reciprocidade das duas ciências.

Outra quebra de paralelismo que emerge da teologia rahneriana é entre teologia e querigma, uma vez que, na intenção de Karl Rahner, a grande tarefa da teologia sistemática consiste em formular a mensagem evangélica para os homens de uma determinada época, de maneira a evitar latentes mal-entendidos, exposições desajustadas e capciosas e também deduções falaciosas das verdades da fé ${ }^{52}$. Já desde o início, Rahner se inquietou com o modo como se ensinava a teologia, o qual não preparava os estudantes para uma proclamação viva da Palavra de Deus. Embora não tendo se associado expressamente àqueles que sustentavam uma teologia querigmática, mesmo porque não via como ela poderia se constituir numa teologia específica, e ainda que o esforço de relacionar a teologia à pregação lhe fosse bem familiar, Rahner dá uma grande importância ao querigma em sua teologia e ao serviço que esta pode prestar a uma maior clareza do

${ }^{51}$ Cf. $S T X$, p. 60. Rahner ilustra bastante a implicação mútua das duas ciências no artigo "Bemerkungen zur Bedeutung der Geschichte Jesu für die katholische Dogmatik", às pp. 215-226 do mesmo $S T X$. O aparato bíblico de que se serve a Teologia Fundamental para fundamentar o discurso teológico não pode desconhecer a crítica literal, estrutural e redacional feita pelos métodos da ciência exegética.

${ }^{52}$ É o quanto aparece do seu artigo "Überlegungen zur Methode der Theologie" in $S T$ IX, pp. 79-126.

${ }^{53}$ Este interesse aparece bastante claro em todas as elucidações dos conceitos teológicos feitas por Rahner (basta ver o KthW) e é um a das preocupações fundamentais da busca de clareza em sua doutrina trinitária. 
anúncio querigmático ${ }^{53}$.

Por isso, a teologia rahneriana não permite que a mensagem bíblica continue sendo vista numa perspectiva e numa forma de pensar cosmocêntricas, quando a autocompreensão e a perspectiva com a qual o homem de hoje olha a realidade são antropocêntricas. Ela procura, pois, superar a tremenda crise de inteligibilidade e credibilidade que recai sobre esta mensagem, traduzindo o querigma no esquema mental antropocêntrico ${ }^{54}$. Numa segunda consideração, insiste em que a teologia, apresentando o querigma em maneira simples e não complicada, não o faça, porém, com uma teologia vulgarizada e secundária. "A simples mensagem evangélica, o querigma mesmo, deve resultar sempre o elemento de maior peso, o mais próximo à realidade ensinada, o mais profundo e o mais empenhativo da mente $\mathrm{e}$ do coração, apesar da sua simplicidade, ou melhor, exatamente por causa da sua simplicidade linear ${ }^{\prime \prime 55}$. Além disso, a teologia sistemática deve figurar como elemento derivado e secundário em relação ao kerigma, porque este "não constitui o discurso primordial sobre a realidade, mas a realidade mesma entendida e experimentada", e, assim, não pode ser substituído pela reflexão teológica ou ser apresentado como subproduto da teologia.

Nesta ótica de compreensão, pode-se concluir, pois, que a teologia de Karl Rahner se caracteriza por uma reflexão onde, em cada um dos seus grandes passos, "o evangelho é colocado e retomado a pretexto de positivos conflitos, a fim de extrair dele uma fecundidade renovada" ${ }^{\prime 56}$. Por isto, estará sempre na berlinda da discussão teológica e eclesial.

Luciano Campos Lavall, presbítero na Diocese de Teófilo Otoni, onde exerce a função de Pároco e de Coordenador Diocesano de Pastoral. É Doutor em Teologia Dogmática pela Pontifícia Universidade Gregoriana (1985) com a tese "O Mistério Santo - Deus Pai na Teologia de Karl Rahner" (São Paulo: Loyola,1987). Publicou também "A afirmação de Deus Pai na Teologia rahneriana" in Perspectiva Teológica no 45 (Mai./Ago 1986) 193213. Atualmente é professor de Filosofia nas Faculdades Doctum - Campus de Teófilo Otoni, e de Teologia Sistemática no Seminário Maior do Nordeste de Minas.

Endereço: Rua Dr. Onofre, 667-A, Centro

39800-022 Teófilo Otoni - MG

e-mail: lucianolavall@uol.com.br

${ }^{54}$ Cf.. K. RAHNER, "Kerygma" in Lexikon für Theologie und Kirche 6, pp. 125-126; K. RAHNER / K. LEHMANN, "Kerygma und Dogma" in Mysterium Salutis I, pp. 622-703. ${ }^{55} S T V$, p. 48.

${ }^{56}$ K. LEHMANN, op. cit., p. 159. 


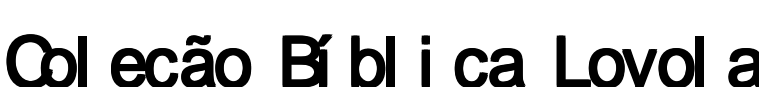

Publicada sob a responsabilidade da Faculdade de Teologia do Centro de Estudos Superiores da Companhia de Jesus.

A Coleção Bíblica Loyola publica estudos, comentários e subsídios bíblicos de nível científico internacional, seja traduzidos do exterior, seja produzidos por biblistas nacionais.

\section{Títulos Publicados}

1. Os Evangelhos I - Mateus e Marcos (G. Barbaglio e R. Fabris)

2. Os Evangelhos II - Lucas e João (R. Fabris e B. Maggioni)

3. Os Atos dos Apóstolos (R. Fabris)

4. As Cartas de Paulo I - Tessalonicenses e Coríntios (G. Barbaglio)

5. As Cartas de Paulo II - Gálatas, Romanos, Filipenses e Filêmon (G. Barbaglio)

6. As Cartas de Paulo III - Colossenses, Efésios, Pastorais e Hebreus (R. Fabris)

7a. A Carta de Tiago (F. Vouga)

7b. As Cartas de Pedro, João e Judas (G. Thevissen et alii)

8. O Apocalipse (P. Prigent)

9. A palavra inspirada (L. Alonso Schökel)

10. A Bíblia como literatura (J. B. Gabel e Ch. B. Wheeler)

11. Cântico dos Cânticos (L. I. Stadelmann)

12. Metodologia do Novo Testamento (W. Egger)

13. Leitura do Evangelho Segundo João I (X. Léon-Dufour)

14. Leitura do Evangelho Segundo João II (X. Léon-Dufour)

15. Leitura do Evangelho Segundo João III (X. Léon-Dufour)

16. Leitura do Evangelho Segundo João IV (X. Léon-Dufour)

17. Jesus e o mundo do judaísmo (G. Vermes)

18. A Galiléia, Jesus e os Evangelhos (S. Freyne)

19. As duas fases da pregação de Paulo (M. Pesce)

20. O Evangelho de Mateus e o judaísmo formativo (J.A. Overman)

21. A Bíblia na Igreja (J.A. Fitzmyer)

22. O pensamento do templo. De Jerusalém a Qumran ( $F$. Schmidt)

23. As formas literárias do Novo Testamento (K. Berger)

24. Procurais o Jesus histórico? (R. Zuurmond)

25. Sabedoria e sábios em Israel (J. Vílchez Líndez)

26. Mulher e homem em Paulo (N. Baumert)

27. A evolução do pensamento paulino (U. Schnelle)

28. Metodologia do Antigo Testamento (H. Simian-Yofre [org.])

29. A mensagem do Reino (R. A. Horsley e N. A. Silberman)

30. Abraão e sua lenda: Gênesis 12,1-25,11 (W. Vogels)

31. Israel e seu Deus: (F. Gradl e F. J. Stendebach)

32. Sacrifício e culto no Israel do Antigo Testamento: (Ina Willi-Plein)

33. O Jesus Histórico: (Gerd Theissen / Annete Merz)

34. A Tríade: fé, esperança e amor em Paulo (Thomas Söding)

Edições Loyola - Cx. P. 42.355 - CEP 04299-970 São Paulo e-mail: vendas@loyola.com.br 